\title{
Research and Development Financing in the Renewable Energy Industry in Brazil
}

\author{
Muriel de Oliveira Gavira, \\ ${ }^{1}$ School of Applied Sciences, University of Campinas, Brazil \\ ${ }^{2}$ DepartmentFaculty of Sciences, University of Lisbon, Portugal \\ e-mail: murielgavira@gmail.com
}

Cite as: Gavira, M. O., Research and Development Financing in the Renewable Energy Industry in Brazil, , J. sustain. dev. energy water environ. syst., 2(3), pp 208-218, 2014, DOI: http://dx.doi.org/10.13044/j.sdewes.2014.02.0017

\begin{abstract}
In the last decades, the Brazilian government has put many public policies in place in order to create a favourable environment to promote energy efficiency and clean energy. In this paper we discuss the use of research and development financing support by the clean energy industry in Brazil. To do so, we carried out an empirical research analysing secondary data from legislation, literature case studies, and public and industry reports in order to determine if the companies of the clean energy industry have public financial support to research and development. Our ongoing research shows that, despite incentives to stimulate the dissemination of clean energy, the participation of some of the clean energy is very small (especially solar). We believe that the contributions of this study will assist policy makers, and the whole industry, to improve clean energy research and development investments in Brazil.
\end{abstract}

\section{KEYWORDS}

Clean energy, Public policy, Energy policy, Innovation, Sustainable development.

\section{INTRODUCTION}

The energy industry has several challenges to face in the next years. The demand for energy is heavily growing in the last years, as a consequence, its exploration, production and distribution costs. Other important challenges are energy security and availability, energy dependency, sustainable development, social justice, etc.

Governments frequently put in place public policies to help society to face such important issues [1]. One way to face many of those challenges is investing in energy efficiency and in clean and renewable energy. These policies deal, mainly, with the supply side of the problem and are able to give diversity of sources reducing energy foreign dependency, energy inequality, harmful environment impacts, and increasing social development [2-5].

Between the instruments of energy policy there are: research and development $(R \& D)$, financing business, tax incentives, voluntary agreements, information dissemination, market reforms, pricing and taxation, consumer awareness, human resources education and training, standard and regulations, and others.

In the last decades, the Brazilian government has put many public policies in place in order to create a favourable environment and to promote energy efficiency and clean energy. Currently, the public sector in Brazil has been directing the resources to the creation of a favourable environment for energy efficiency and renewable energy initiatives.

The biggest and most successful Brazilian policy regarding the renewable energy industry was the PROALCOOL (Alcohol National Program). As a result, Brazil is today 
one of the leaders in the use of biomass to generate energy (electricity and transportation).

Apart from the sugarcane industry, the government has put in place policies and incentives to clean energy sources such as solar, wind, and biofuel. As Brazilian government also intends to promote the technological development of the country, these incentives include financial support to research and development (R\&D), such as the Program of Incentives for Alternative Electricity Sources (PROINFA) and the Technological Development Program for Biodiesel.

In the case of $R \& D$ policy, governments can support those activities through financing incentives, governmental purchase of high technological goods and services, public research, rights of intellectual propriety, and human resources for innovation.

To meet the energy challenges we need to develop new technologies and to innovate in ways of efficiently use of the present ones. Therefore, investing in R\&D for new and improved clean energy systems is fundamental to the adoption of clean energy technologies.

In the energy industry, is particularly relevant to invest in energy efficiency, computing, information technologies, grid management, and low-carbon technologies and process. Also very important is to expand financing instruments to basic science in the areas of fuel cells, hydrogen, advanced renewable energy, modern biofuels and energy storage [6].

In this paper we discuss the results of an ongoing research about $R \& D$ financing to renewable energy projects in Brazil and to do so, we carried out an empirical research analysing secondary data from legislation, literature case studies, and public and industry reports in order to determine if the companies of the renewable energy industry, especially new renewable power generation, have benefit from governmental financial support to R\&D projects.

\section{RENEWABLE ENERGY IN BRAZIL}

It is important to know the main indicators of the renewable energy industry in Brazil in order to understand where are the technological and productive gaps in the sector.

According to IBGE [7] 191 million people lived in Brazil in 2010 and $98 \%$ of them had access to the power grid (2008 data). With a population of this size and the exhaustion of the hydropower potential, it is crucial to seek for new sources of energy in Brazil and to promote energy efficiency and distributed forms of electricity generation.

Brazil relies heavily on clean energy sources: about $46 \%$ of the country's energy comes from renewable sources, and with the main source of power energy is being hydroelectric power. Additionally, as stated before, because Brazil invested early in ethanol as a result of government incentives put in place in the mid-1970s, today, it is a world leader in ethanol exports and in the use of biomass to produce electricity in the industrial sector [8].

According to EPE [4] clean energy sources (wind, biomass, small hydro, etc.) will increase their participation in the electricity sector in Brazil from $47.5 \%$ in 2010 to $46.3 \%$ in 2020 . In 2010, $19.3 \%$ of the primary energy production came from sugarcane products, $13.7 \%$ from hydropower, $10.2 \%$ from wood, and $4.3 \%$ from other renewable sources.

Despite the increase of clean energy generation in Brazil, especially biomass and wind (Figures 1 and 2, and Table 1), the proportion of renewable sources in the total electricity installed capacity has been falling in the last 12 years. Comparing to other countries, Brazil still have a large share of renewable sources (including hydropower) of electricity; however countries such as Germany, France and the United States have increased the participation of renewable sources in their grid. 
In addition, in Figure 2 one can see that the participation of new renewable sources, excluding hydropower, and their installed capacity is still very small considering the country's potential. Moreover, fossil fuel thermal energy has been growing faster than the renewable.

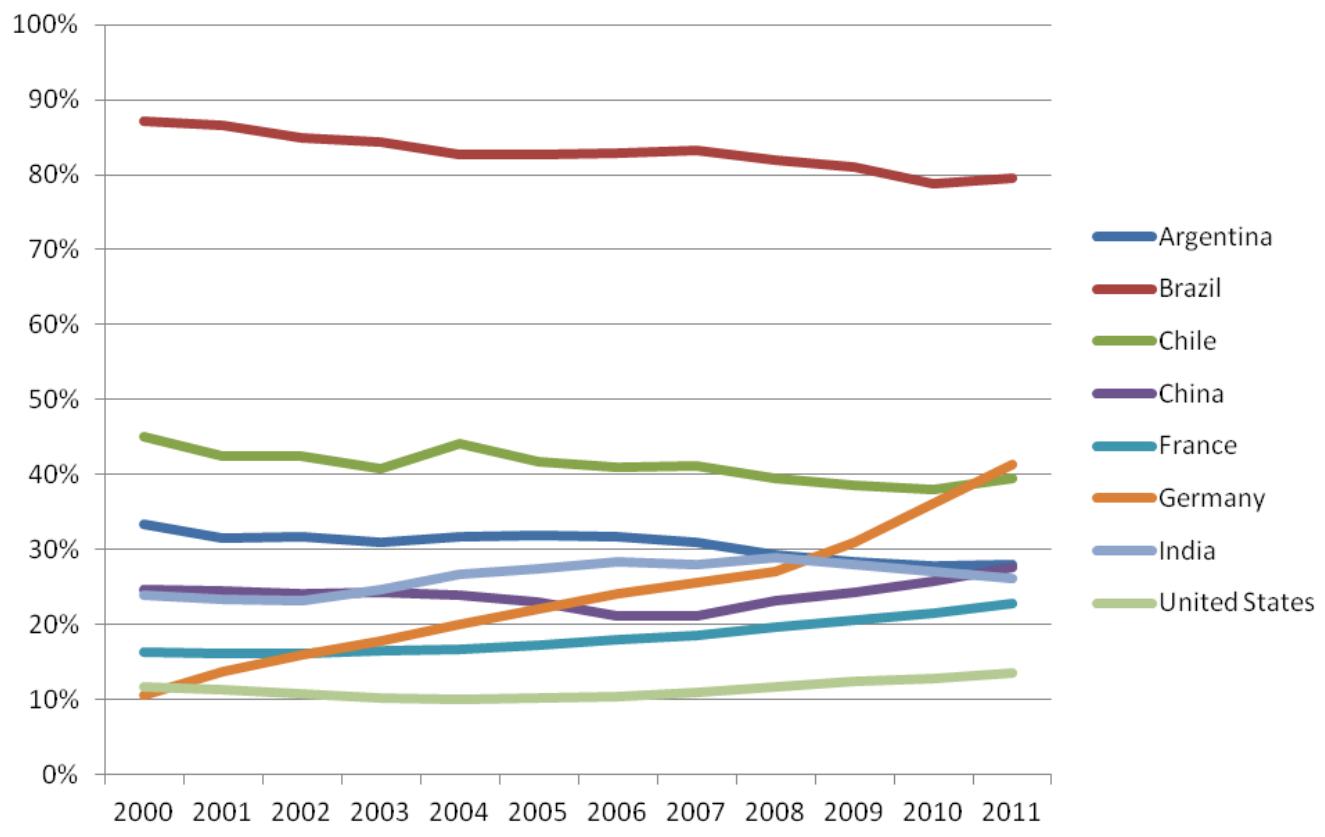

Figure 1. Participation of the renewable sources in the total Electricity Installed Capacity in selected countries

(Source: Elaborated with data from [9])

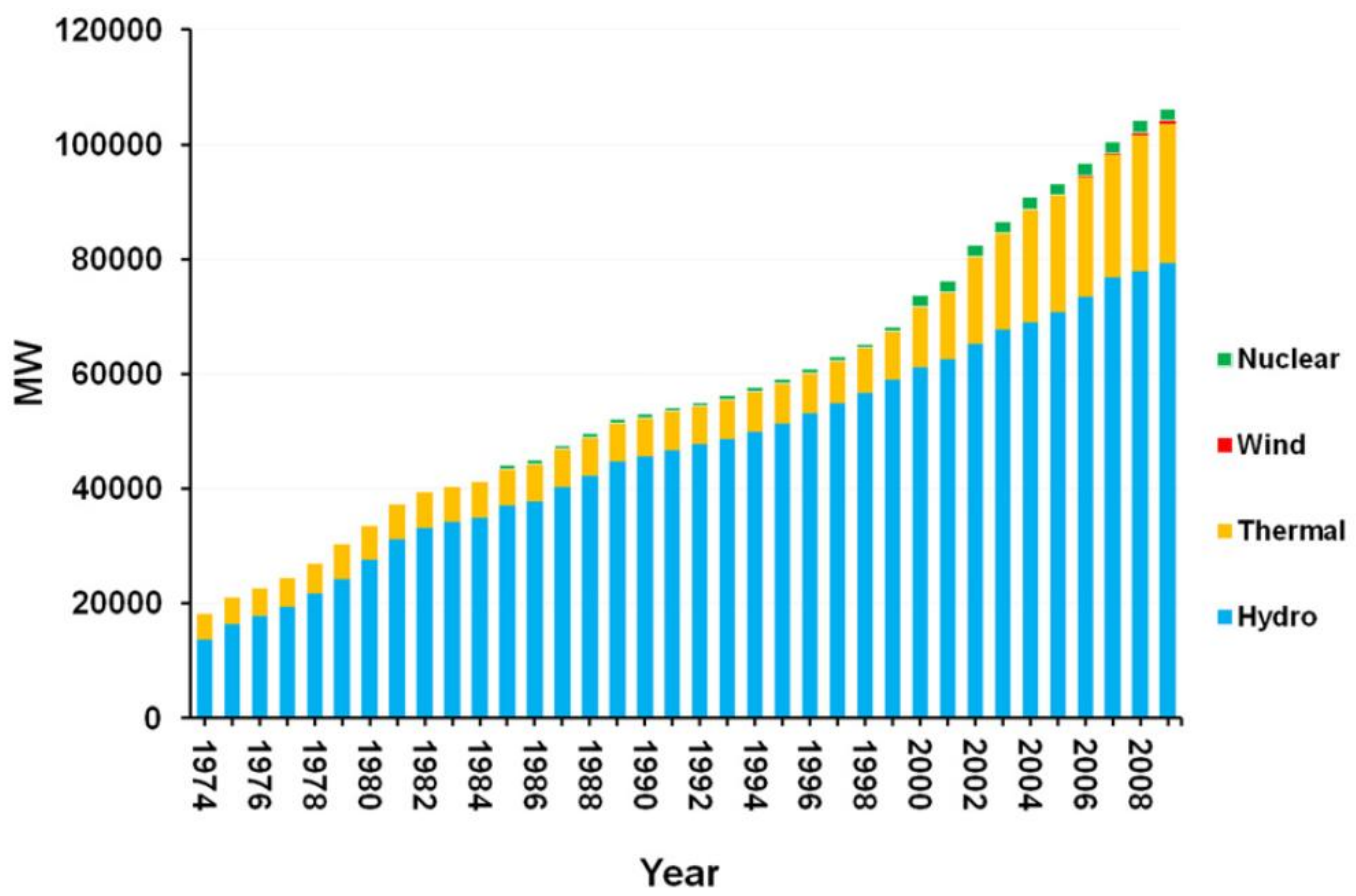

Figure 2. Installed Capacity of Electric Generation [MW]

(Source: Adapted from [4])

On the other hand, Table 1 shows a significant participation of thermal sources in the installed capacity of the country. The Brazilian government have been investing in 
thermal power plans and their production increase from $2,178 \times 10^{3}$ tep (toe) in 2000 to $6,845 \times 10^{3}$ tep (toe) in 2012 [4].

Wind generation has increasing participation in the last years (from $1 \mathrm{GWh}$ in 2000 to 2.176 GWh in 2010) but the wind farms are generally in the Northeast, far from the main consumer centres, due to the climate characteristics and distance from large urban areas.

Table 1. Installed Capacity of Electric Generation [MW] in 2010

\begin{tabular}{lccccccccc}
\hline Region/Sources & \multicolumn{3}{c}{ HYDRO } & \multicolumn{3}{c}{ THERMAL } & \multicolumn{3}{c}{ WIND } \\
\hline & SP & APE & Total & SP & APE & Total & SP & APE & Total \\
Brazil & 77,318 & 3,385 & 80,703 & 17,548 & 12,141 & 29,689 & 926 & 2 & 928 \\
North & 10,866 & 29 & 10,895 & 3,029 & 365 & 3,394 & & & \\
Northeast & 10,776 & 167 & 10,943 & 3,967 & 1,953 & 5,920 & 722 & 2 & 724 \\
Southeast & 22,661 & 1,892 & 24,553 & 6,034 & 7,662 & 13,695 & 29 & & 29 \\
- São Paulo & 10,442 & 542 & 10,984 & 1,145 & 4,714 & 5,859 & & & \\
South & 22,042 & 1,143 & 23,186 & 3,178 & 1,006 & 4,185 & 175 & & 175 \\
Centre-West & 10,972 & 154 & 11,126 & 1,340 & 1,156 & 2,496 & & & \\
\hline
\end{tabular}

Notes: SP - Public Service. APE - Self-Producers (excluding the partnership between hydroelectric plants with Public Service concessionaries as: Igarapava, Canoas I and II, Funil, Porto Estrela, Machadinho and others).

Source: Elaborated with data from [4]

Other characteristics of the Brazilian Electricity System are [5, 10, 11]:

- The distribution of power is uneven: the access is smaller more limited in the North and Northeast regions; but also these regions have a much smaller population;

- The privatization in the sector started in the mid 1990's;

- The transmission network is integrated (National Integrated System in the states of South, Southeast and Northeast of Brazil). This integrated system cover about 98\% of the electricity demand of Brazil and is dominated by hydropower plants with large reservoirs. There are also isolated systems in the North of Brazil, mostly thermal;

- In 2010 there were 98,648.32 km of transmission lines in the National Integrated System (an increase of 3\% compared to 2009);

- Power generation and transmission are, for the most part, State controlled. Around $60 \%$ of the power distribution (installed capacity) is managed by private companies. Figure 3 shows that the generation is dominated by public utility power plants.

In the world, Brazil is number four in renewable power capacity when hydropower is included [11], and number five in terms of annual capacity increment. Such an increment is largely due to ethanol and biodiesel products (Brazil is number two in biomass power), with wind and solar PV power still being incipient. Brazil is developing new projects related to wind power, solar power, and tidal and wave energy, in order to explore its largely untapped potential [4].

The expansion of the power generation from cleaner sources is promising for Brazil, especially considering that the country can benefit from carbon trading with countries with emission goals. The case of ethanol, which is already exported to several countries, 
is particularly relevant. But, to tap such a potential, the country needs to develop more sustainable ways of growing sugar-cane and producing ethanol.

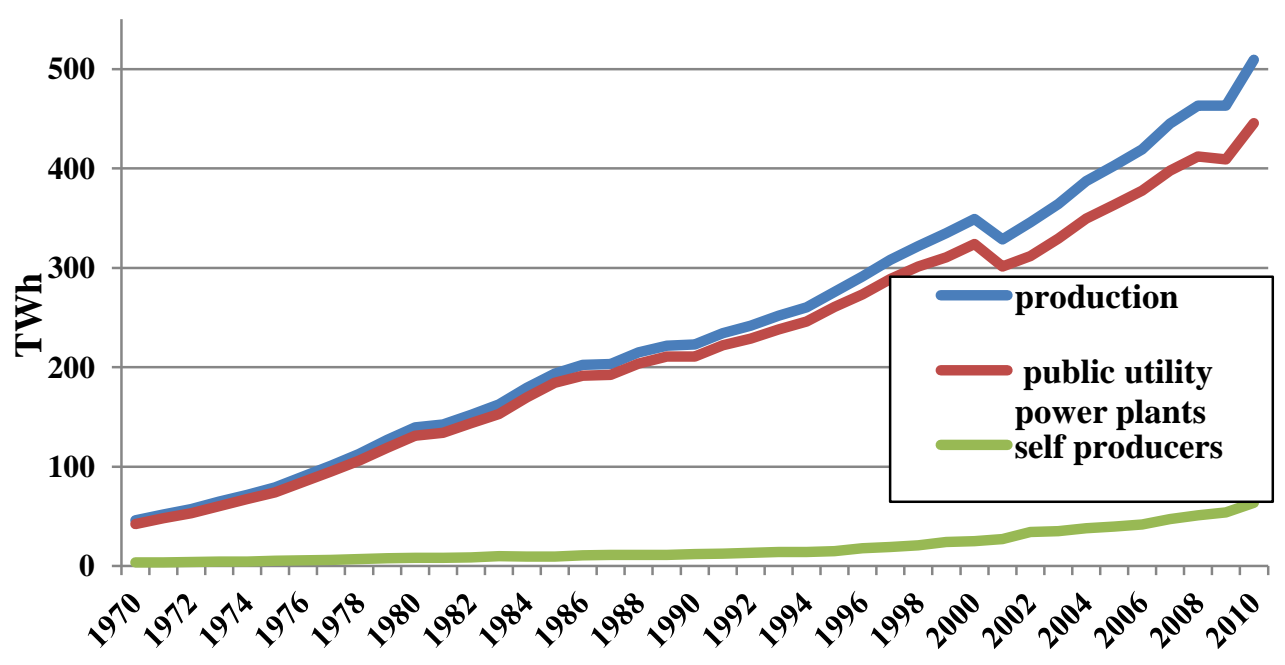

Figure 3. Electricity production in Brazil (flow)

(Source: Elaborated with data from [4])

\section{POLICY INSTRUMENTS FOSTERING RENEWABLE ENERGY IN BRAZIL}

Market and technological uncertainties to which clean energy investments are subject may be mitigated by a good institutional and regulatory environment. Well-planned policies and support mechanisms help actors to manage risks and opportunities in the energy industry. In this context, $\mathrm{R} \& \mathrm{D}$ has an important role in promoting renewable electricity since it might result in new and improved innovation to the industry.

Enzensberger et al. [10] divide the policy instruments fostering renewable energy is two larger groups: legislative measures and non-legislative measures. We adapted Enzensberger et al.'s typology to consider R\&D financing (Figure 4) and list some examples of instruments:

- Demand and control;

○ R\&D: mandatory investments in R\&D (utilities in Brazil must invest $0.5 \%$ of their Net revenue in R\&D - Lei $n^{\circ}$ 9.991/2000);

o Other instruments: mandatory investments in general, shut-downs, mandatory fuel off-take.

- Construction incentives;

○ R\&D Financing: low or no interested financing;

o Other instruments: accelerated depreciation, subsidies, tax deduction and low interested loans.

- Production incentives: fixed feed-in tariffs, tax exemption, actions, etc.;

- Demand-pull: renewable portfolio standard with certificate trading, tax deductions for purchase; public purchase of technology and energy;

- Voluntary: certification, self-goal, etc.;

- Informative or administrative: improvement of administrative process; investor advising; publicity; resource mapping;

- R\&D: investments in R\&D for energy efficiency and renewable energy. 


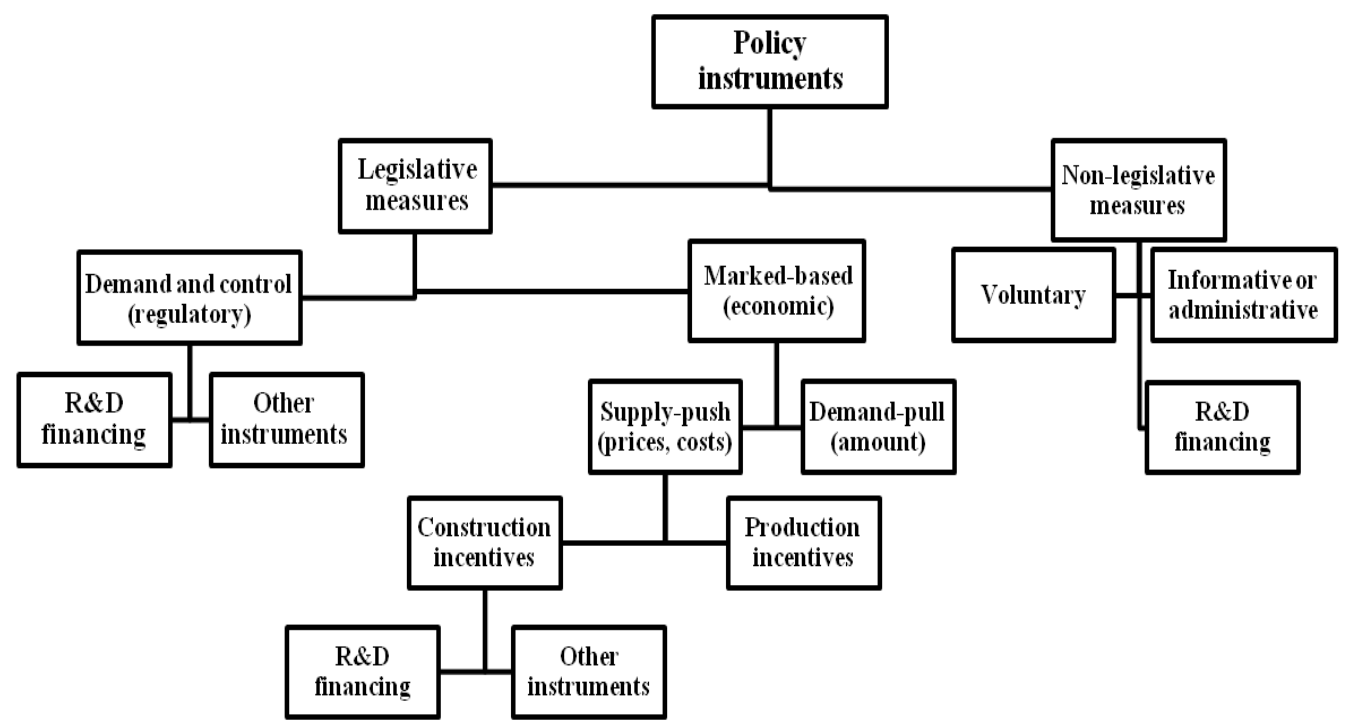

Figure 4. Typology of policy instruments

(Source: adapted from [10])

Research and development (R\&D) policies aim to reduce the cost and risk of those activities in order to improve the quantity and quality of the innovation efforts in the country. Regarding public support, the government might offer support instruments such as:

- Tax incentives such as discounts on income taxes based on the amount of R\&D investments;

- Taxation over carbon intensive energy sources;

- Direct public financing of R\&D projects;

- Financing R\&D public institutes that might involve companies in their projects;

- Public purchase of technology and electricity;

- Others: venture capital, public-private partnerships, etc.

In this paper we focus only in direct public R\&D financing from market-based (see Figure 4) to the renewable energy industry in Brazil. We do not intend to analyse the $R \& D$ investments of the utilities companies in Brazil.

Moreover, the financial incentives to $R \& D$ can be classified according to its topic, that is, resources (input), such as labour, machinery and equipment, infrastructure (buildings, information networks, etc.), overhead costs, technological services, materials, etc. Also, it includes incentives that support project development, and output goods and knowledge (licensing process, knowledge management, etc.) [13]. In this paper we focus in all these topics.

\section{Direct public research and development financing}

Only in the 1990's Brazil put in place better and reliable instruments of public R\&D financing for the private sector. Since then one could see the expansion and diversification of the funding in order to ensure a better resources allocation. However, only part of this goal was, in fact, achieved [11,13] and Bastos [1]. In Table 2 we present the main sources of public financing to the energy industry in Brazil. 
Table 2. Main sources of public R\&D financing to the renewable energy industry in Brazil

\begin{tabular}{|c|c|}
\hline Type & Institutions \\
\hline \multicolumn{2}{|l|}{ National funding } \\
\hline $\begin{array}{l}\text { Federal } \\
\text { Funding } \\
\text { agencies }\end{array}$ & $\begin{array}{l}\text { Science and technology agencies from the Ministry of Science, Technology } \\
\text { and Innovation (MCTI) such as National Innovation Agency (FINEP); } \\
\text { National Council for Scientific and Technological Development (CNPq). } \\
\text { Regional development agencies such as Amazon Development Agency } \\
\text { (Sudam) and The Superintendence for the Development of the Northeast } \\
\text { (Sudene). } \\
\text { Regulatory agencies: The Brazilian Electricity Regulatory Agency (Aneel); } \\
\text { National Agency of Petroleum, Natural Gas and Biofuels (ANP); etc. }\end{array}$ \\
\hline $\begin{array}{l}\text { Federal } \\
\text { program }\end{array}$ & $\begin{array}{l}\text { Technological support program for exports (Progex), Constitutional Fund } \\
\text { for Financing the Centre West Region; etc. }\end{array}$ \\
\hline State programs & $\begin{array}{l}\text { State funding to support research such as Fundes (RJ), Fomento (GO), and } \\
\text { other research funds. }\end{array}$ \\
\hline $\begin{array}{l}\text { Research } \\
\text { Foundations }\end{array}$ & $\begin{array}{l}\text { Banco do Brasil Foundation (FBB); states foundations such as São Paulo } \\
\text { Research Foundation (Fapesp); Research and Development Foundation } \\
\text { (FADESP); Foundation to Support Research and Extension (Fapex); etc. }\end{array}$ \\
\hline Banks & $\begin{array}{l}\text { Banco do Brasil; Brazilian Social and Economic Development Bank } \\
\text { (BNDES); etc. }\end{array}$ \\
\hline \multicolumn{2}{|c|}{ International funding } \\
\hline Programs & $\begin{array}{l}\text { Global Environment Facility, United Nations Environment Programme } \\
\text { (UNEP). }\end{array}$ \\
\hline Banks & $\begin{array}{l}\text { The Inter-American Development Bank (IADB or BID), World Bank, The } \\
\text { International Bank for Reconstruction and Development (IBRD). }\end{array}$ \\
\hline
\end{tabular}

Source: Adapted from $[16,17]$

In Table 3 we present the main support to the clean energy industry in Brazil. One can note a variety of different institutions managing the support programs with similar objectives but different types of support instruments. In this way, it is important to have a central institution to guarantee that those instruments work together for the development and diffusion of relevant innovations in the clean energy industry.

In this paper we focused the programs of one its institution: The National Innovation Agency (FINEP).

Finep is directly responsible for the financing of $R \& D$ project in Brazil and it is the main source of $R \& D$ financing in the last years $[18,7]$. This institution issues loans and grants to public and private institutions in Brazil. The grants come from The National Fund for Scientific and Technological Development (FNDCT). It is also is responsible for managing the most part of the Sector Funds of Science, Technology and Innovation and for programs such as $[2,8]$ :

- Long-term credit with reduced interest rates;

- Concession of economic subsidy for the R\&D activity;

- Fiscal incentives: information law, innovation law, etc.;

- Non-reimbursed resources;

- Seed money;

- Scholarships;

- Programs to support the interaction among universities, public research institutions and companies;

- Develop the venture capital segment in Brazil (project "inovar"). 
Table 3. Main support programs to the clean/renewable energy industry in Brazil

\begin{tabular}{|c|c|c|c|c|c|}
\hline Program & $\begin{array}{l}\text { Management } \\
\text { Institution }\end{array}$ & $\begin{array}{l}\text { Type of } \\
\text { support }\end{array}$ & Implanted & $\begin{array}{c}\text { Specific to } \\
\text { the energy } \\
\text { industry }\end{array}$ & Main objective \\
\hline PROINFA & Eletrobras & $\begin{array}{l}\text { Guaranteed } \\
\text { contracts of } \\
\text { energy purchase }\end{array}$ & 2002 & $\begin{array}{l}\text { Yes, biomass, } \\
\text { wind and } \\
\text { small hydro }\end{array}$ & $\begin{array}{l}\text { Increase the share of } \\
\text { renewable energy in the } \\
\text { National grid from } \\
\text { independent power } \\
\text { producers }\end{array}$ \\
\hline $\begin{array}{l}\text { CT- } \\
\text { ENERG }\end{array}$ & $\begin{array}{l}\text { National } \\
\text { Innovation } \\
\text { Agency } \\
\text { (FINEP) }\end{array}$ & $\begin{array}{l}\text { R\&D and } \\
\text { innovation } \\
\text { projects } \\
\text { financing }\end{array}$ & 2001 & $\begin{array}{l}\text { Renewable } \\
\text { power } \\
\text { generation } \\
\text { and Efficient } \\
\text { energy use }\end{array}$ & $\begin{array}{l}\text { Energy security and } \\
\text { diversification, lower } \\
\text { costs, increase quality } \\
\text { of services, and } \\
\text { increase the } \\
\text { competitiveness of } \\
\text { domestic technology. }\end{array}$ \\
\hline InovaEnergia & $\begin{array}{l}\text { Brazilian } \\
\text { Social and } \\
\text { Economic } \\
\text { Development } \\
\text { Bank } \\
\text { (BNDES) }\end{array}$ & $\begin{array}{l}\text { R\&D financing: } \\
\text { several } \\
\text { instruments such } \\
\text { as long- term } \\
\text { credit with } \\
\text { reduced interest } \\
\text { rates; } \\
\text { non-reimbursed } \\
\text { resources. }\end{array}$ & 2013 & $\begin{array}{l}\text { Yes, to } \\
\text { equipment } \\
\text { suppliers to } \\
\text { the renewable } \\
\text { energy } \\
\text { industry. }\end{array}$ & $\begin{array}{l}\text { Support Brazilian } \\
\text { companies in the global } \\
\text { technological develop- } \\
\text { ment and production of } \\
\text { the photovoltaic, } \\
\text { thermo solar and wind } \\
\text { power technologies. }\end{array}$ \\
\hline $\begin{array}{l}\text { Law } \\
9991 / 2000\end{array}$ & $\begin{array}{l}\text { The Brazilian } \\
\text { Electricity } \\
\text { Regulatory } \\
\text { Agency } \\
\text { (Aneel) }\end{array}$ & $\begin{array}{l}\text { Mandatory } \\
\text { investments in } \\
\text { renewable } \\
\text { energy and } \\
\text { energy } \\
\text { efficiency }\end{array}$ & 2000 & $\begin{array}{l}\text { Yes, } \\
\text { renewable } \\
\text { energy and } \\
\text { energy } \\
\text { efficiency }\end{array}$ & $\begin{array}{l}\text { To promote constant } \\
\text { innovation to overcome } \\
\text { the technological } \\
\text { challenges of the power } \\
\text { industry. }\end{array}$ \\
\hline
\end{tabular}

Finep's objective is to support the creation and development of:

- Technology-based businesses that emerge from research centres and universities;

- High-tech spin-offs from large businesses;

- Technology parks;

- Technology-based business incubators;

- Of innovative Clusters;

- Of private research Centres.

In Figure 5 one can see a significant increase in Finep's disbursements in the last years.

The Brazilian science and technology sector funds aim to expand and ensure the constancy of the R\&D financing in Brazil and were created to complement and incentive the R\&D development in strategic sectors to the county, such as energy, oil, Amazon, agribusiness, biotechnology, etc.

To this research, the most important funds are: Energy, Infrastructure, and "Verde Amarelo". 
To participate the companies wait for the calls for projects and them present the proposals, then Finep evaluate the proposals. The call pays expenses such as R\&D infrastructure, services, material, equipment, scholarships, etc.

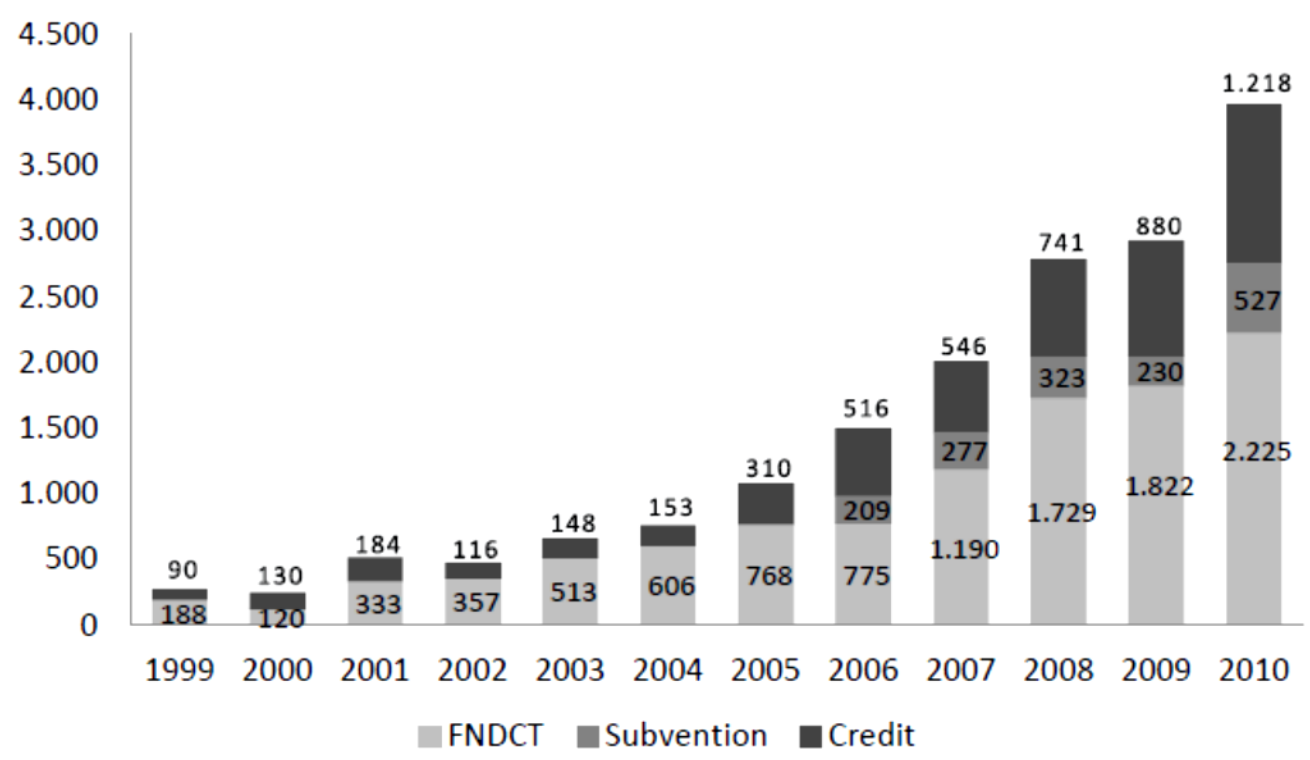

Figure 5. FINEP's disbursements, by program (in local currency - BRL millions), 1999-2010 [19]

The funds Verde Amarelo (FVA) and Infrastructure (CT-Infra) are cross sector and the Energy one (CT-Energ) is specific to the electricity industry.

In recent years Brazil has put in place important initiatives to improve funding opportunities for R\&D projects. Major challenges still are the integration between the public funding and develop research and the private sectors and the stability and constancy of funding programs.

The Brazilian financial supports have approximated to those found in other countries, especially OECD countries [2]. These supports have been intensified not only in financing, institutional and incentives resources; but also, in the integration between industrial and economic policies. Those actions aim to increase and improve the integration between the instruments and actors, the knowledge diffusion, the innovation culture, and the competitive advantage derived from technological innovation.

Brazil is far of its goals, once there is still a centralization of recourses and decision making in few institutions, especially FINEP (Financiadora de Estudos e Projetos Research and Projects Financing) and BNDES (Banco Nacional de Desenvolvimento Econômico e Social - Brazilian Development Bank).

Another issue of considerable importance is the consistency and stability of funding and incentives. That has not happened in recent years because of the resources subordination to national tax problems $[2,19]$.

\section{CONCLUSION}

Well-planned policies and institutional mechanisms can help actors to address risks and exploit opportunities. Indeed, market uncertainties and technological risks in sustainable energy investments are very high, giving to the regulatory environment an essential role in support of multilevel initiatives. 
Moreover, since the technological costs and risks in the energy industry are very high, the government should support and incentive the sector to develop itself in a more competitive speed than the present one.

In the last years, the Brazilian government has invested in the creation of policies and incentives aimed at energy efficiency and at other clean energy sources such as solar, wind, and biofuel. Countries have also put into place Science and Technology (S\&T) Policies to support Education and Research and Development activities. In Brazil, several initiatives are in place, such as the Program of Incentives for Alternative Electricity Sources (PROINFA) and the Technological Development Program for Biodiesel and the Program for the Hydrogen Economy.

Considering public financial support to innovate, in recent years Brazil has taken important initiatives to improve funding opportunities for projects to research, development and innovation. The main challenge lies on the integration between private (firms) and knowledge generation sectors (universities etc.) and on the constancy financing instruments.

Another issue of considerable importance is the consistency and stability of funding and incentives. That has not happened in recent years because of the resources subordination to national budget problems.

Our ongoing research shows that, despite incentives to stimulate the dissemination of clean energy, the participation of some of the clean energy is very small (especially solar). In addition, the financial resources that the energy industry use to research and develop new clean technologies is still scarce, especially considering the potential of Brazil. However, that amount has increased in the last years, with focus on energy efficiency and hybrid vehicles the country needs to make a better effort in placing mechanisms for awareness, support (especially financial) and promotion of $R \& D$ in the renewable industry.

It is still not clear if those policies bring benefits to the country, such as energy security, diversification of the power grid, reduction of foreign oil dependency, and technological development. It is evident that for the clean energy industry to develop, the country needs to invest more in innovation and in mechanisms of awareness, and support.

The fact that the Brazilian energy grid is considered one of the cleanest in the world may cause the government to accommodate and lose sight of a bigger picture that embeds great opportunities for institutional and technological improvements towards a sustainable energy industry.

We believe that the contributions of this study will assist policy makers, and the whole sector, to improve clean energy research and development investments in Brazil.

The next step of our research is to study the results of research and development founding in Brazil from Finep and BNDES especially from the Sectors Funds and the Program of Incentives for Alternative Electricity Sources (PROINFA).

\section{REFERENCES}

1. Bastos, V. D., Public funds for science and technology (in Portuguese), Revista do BNDES, Vol. 10, no. 20, pp. 229-260, 2003.

2. Corder, S., Financing and incentives to the innovation system in Brazil: current situation and perspectives, Ph.D thesis, UNICAMP, Instituto de Geociências, Departamento de Política Científica e Tecnológica, Campinas, ago. 2004. Retrieved from: http://www.bibliotecadigital.unicamp.br/document/?code=vtls000349489, [Accessed: 12-Dec-09], (in Portuguese)

3. Economist Intelligence Unit - EIU, Scattering the seeds of invention: the globalisation of research and development, 2004. Retrieved from: 
http://graphics.eiu.com/files/ad_pdfs/RnD_GLOBILISATION_WHITEPAPER.pdf , [Accessed:04-April-12]

4. Energy Research Company - EPE (Brasil), Brazilian Energy Balance Year 2012, Rio de Janeiro, 2013.

5. International Energy Agency - IEA, Renewables in global energy supply: an IEA fact sheet, International Energy Agency, 2007.

6. Energy Research Company - EPE (Brasil), National Energy Plan 2020, Rio de Janeiro, 2011.

7. The Brazilian Institute of Geography and Statistics - IBGE, 2010 Population Census, IBGE, 2011.

8. Alvarenga, G. V., Pianto, D. M. and Araújo, B. C., Impacts of the Brazilian science and technology sector funds on industrial firms' R\&D inputs and outputs: new perspectives using a dose-response function. In: Proceedings, EncontroNacional de Economia - ANPEC, Porto de Galinhas (PE): Anpec, 11-14 Dec, 20 12. Retrieved fromhttp://www.anpec.org.br/encontro/2012/inscricao/files_I/i8-5fe1cb9e5d777ea4 0cd1a965ecfba0b8.pdf, [Accessed: 13-Sep-13]

9. U.S. Energy Information Administration - EIA. International Energy Statistics. Retrieved from: http://www.eia.gov/countries/, [Accessed: 28-Feb-14]

10. Enzensberger, N., Wietschel, M., and Rentz, O., Policy instruments fostering wind energy projects-a multi-perspective evaluation approach, Energy Policy, Vol. 30, no. 9, pp. 793-801, 2002., http://dx.doi.org/10.1016/S0301-4215(01)00139-2

11. REN21, Renewables 2011 Global Status Report, Paris, REN21 Secretariat, 2011. Retrieved from: http://www.map.ren21.net/GSR/GSR2012.pdf [Accessed: 06-Nov-12]

12. Heugens, P. P. M. A. R. and Lander, M., Structure! Agency! (and other quarrels): meta-analyzing institutional theories of organization, Academy of Management Journal, Vol. 52, No. 1, pp 61-85, 2009., http://dx.doi.org/10.5465/AMJ.2009.36461835

13. Lundvall, B-Å., National Innovation Systems: towards a theory of innovation and interactive learning, Pinter, London, 1992.

14. Nelson, R., National Innovation Systems: a comparative analysis, Oxford University Press, New York/Oxford, 1993.

15. Organisation for Economic Co-operation and Development - OECD, Education at a Glance 2012: OECD Indicators, OECD Publishing, 2012.

16. Organisation for Economic Co-operation and Development - OECD, World Energy Outlook 2011 Fact Sheet: global energy trends, 2011.

17. Pereira, N. M., Fundos setoriais: avaliação das estratégias de implementação e gestão, White paper n. 1.136, Brasília, 2005.

18. Pereira, N. M., Sector Funds: evaluation of implementation and management strategies (in Portuguese), White paper n. 1.136, Brasília, 2005. Retrieved from: http://www.ipea.gov.br/pub/ td/2005/td_1136.pdf, [Accessed: 15-Feb-2007]

19. Pereira, N. M., and Simone P. F. Experiences to support sector technological innovation (in Portuguese), Journal of Technology Management \& Innovation, Vol. 1, No. 3, pp 74-80, 2006. 